\title{
Article \\ Improvement of Pavement Subgrade by Adding Cement and Fly Ash to Natural Desert Sand
}

\author{
Talal S. Amhadi *(D) and Gabriel J. Assaf \\ Department of Civil Engineering and Construction, École de Technologie Supérieure (ÉTS), University of Québec, \\ 1100 Notre-Dame West, Montréal, QC H3C, Canada; gabriel.assaf@etsmtl.ca \\ * Correspondence: talal.amhadi.1@ens.etsmtl.ca
}

Citation: Amhadi, T.S.; Assaf, G.J. Improvement of Pavement Subgrade by Adding Cement and Fly Ash to Natural Desert Sand. Infrastructures 2021, 6, 151. https://doi.org/ $10.3390 /$ infrastructures6110151

Academic Editors: Yetkin Yildirim,

Gokhan Saygili and

Giuseppe Loprencipe

Received: 30 July 2021

Accepted: 15 October 2021

Published: 23 October 2021

Publisher's Note: MDPI stays neutral with regard to jurisdictional claims in published maps and institutional affiliations.

Copyright: (c) 2021 by the authors. Licensee MDPI, Basel, Switzerland. This article is an open access article distributed under the terms and conditions of the Creative Commons Attribution (CC BY) license (https:/ / creativecommons.org/licenses/by/ $4.0 /)$.

\begin{abstract}
Soil characteristics are paramount to design pavements and to assess the economic viability of a road. In the desert, such as that found in southern Libya, the very poor quality of soils leads to important pavement distress such as cracks, rutting, potholes, and lateral shear failure on the edges. To improve the strength of desert sand, an innovative approach is proposed, consisting of adding manufactured sand, ordinary Portland cement (OPC), and fly ash (FA) as a binder. OPC and FA improve the characteristics of mixes of crushed fine aggregate (CFA) and natural desert sand (NDS). These results are based on a gradation of two sand sources to determine the particle distribution and X-ray fluorescence (XRF) to determine their chemical and physical properties, respectively. This research assesses the effect of cement and fly ash on the geotechnical behavior of two mixtures of fine desert and manufactured sands (30:70\% and 50:50\%). The mix composed of $26 \%$ of CFA, $62 \%$ of NDS, $5 \%$ of OPC, and $7 \%$ of FA shows optimal results in terms of strength, compaction, and bearing capacity characteristics.
\end{abstract}

Keywords: cement; fly ash; pavement construction; UCS; soil stabilization; CBR

\section{Introduction}

Transportation network efficiency is crucial for the functioning of the world economy. Roads are some of the oldest and most popular modes of transportation [1]. The pavement materials used in the building of roads fall into two broad categories of rigid and flexible, respectively. The cement concrete layer in rigid pavement is primarily load bearing, while the asphalt layer in flexible pavement is the wearing course [2,3]. Pavement design must account for the increase in road use and technological innovation that gives vehicles greater load-bearing capacity, since road structural integrity can be compromised from the corresponding increase in stress $[4,5]$. Road structure is typically made up of four layers, which include the wearing course, base course, subbase course, and subgrade. The effective transfer of design axle load from the top to the adjacent layers of the pavement depends on the materials, mechanical properties, and thickness of the respective layers [6]. The subgrade layer has the lowest California-Bearing Ratio (CBR) and maximum dry density (MDD) of all other layers, and it is also the most plastic with the highest plasticity index (PI). As well, environmental conditions including high groundwater table can significantly weaken subgrade soil [7]. Pavement design accounts for these environmental issues by using thicker above subgrade road layers, a more robust material in lieu of subgrade, or overall stronger, more rigid pavement [8].

The characteristics of a soil for road construction is critical in a feasibility study: the poor quality of soils, especially in desert areas, challenges the pavement design and the economic viability of a road project. In deserts, the absence of water explains the formation of soils through the effects of erosion, heavily blowing winds, sedimentation, and important temperature changes between day and night, which results in the breakdown of the rocks into sand or gravel [9]. The fine-grained, round-shaped, and smooth nature of desert sands leads to poor strength. The typical round shape of desert sand grain affects the 
mechanical interlock between aggregates, and after adding cement, that affects the stability of the mixture and the fresh concrete properties [10]. Therefore, desert sand does not often meet the technical requirements to be used as a pavement subgrade if untreated [11]. The use of desert sand for construction purposes has recently gained attention as it improves the physical and chemical properties of mortar [12]. The strength of the desert sand concrete (DSC) is equivalent to that of the ordinary concrete [13-15]. However, the physical and mineral composition of desert sands varies depending on regions where they are formed [16].

Cost can be a significant barrier to implementing the above strategies, and it is best to exhaust all available options for improving the existing subgrade properties before replacing it. Subgrade can be stabilized using a variety of pozzolanic and industrial materials including lime, fly ash, silica fume, cement, and bentonite, among others [17]. Additionally, sourcing usable road-building materials from construction waste can be an effective waste management strategy. Coal consumption produces large amounts of fly ash, which is a low-cost and reusable construction material [18]. Despite its common use in construction, fly ash remains an under-researched material and source of potentially useful compounds with interesting properties. One study uses the combination of cement, polymers, enzymes, and fly ash for the stabilization of subgrade soil. The bearing capacity of soil was found to be improved using a mixture of fly ash, cement and enzymes, consequently reducing the overall road layer thickness [19].

The process of stabilizing the desert soil with cement decreases its compressibility and its permeability, and it further increases its strength, its bearing capacity, and its durability. It also reduces construction cost by utilizing local materials [20,21]. Furthermore, the use of cement to improve the engineering properties of soils has already been adopted [22-25], and this is mainly due to the hardening of cement in the presence of moisture and during the curing period [26]. Previous study on the effect of demolition waste on the compaction properties and unconfined compressive strength of weak soil [27] showed that the addition of waste particles decreases the optimum water content and increases the dry unit weight of clay, while the unconfined compressive strength increased quite significantly with the addition of concrete particles.

Cement-lime has been used with good results to stabilize fine and granular soils as well as fine aggregates. Indeed, the lime (i.e., calcium hydroxide) interacts and modifies the clay found in the soil [28]. At the same time, fly ash creates a bond between the particles, limiting the expansion and contraction of the material and therefore the expansion in volume of plastic soils. This phenomenon is similar to the Portland cement effect, which limits the fluctuation in concrete mixes. The main objectives of this study are as follows: (1) protect the environment by using the cement-fly ash with NDS from quarry materials in engineering projects, (2) investigate the effect of using a combination of fly ash-cement as a stabilizer on the engineering properties of the subbase and base layers, and (3) develop useful and practical relationships between strength, compaction, and the California bearing ratio (CBR) of the treated desert sand materials for practical use in the construction industry.

\section{Laboratory Investigation}

A laboratory testing program was undertaken to achieve the objectives of the study. Laboratory tests were conducted on untreated and treated soil with a cement-fly ash admixture. These soil mixtures stabilized with varying percentages of fly ash (i.e., 3, 5, and $7 \%$ ) with a constant cement content $5 \%$. The samples were investigated to determine their influence on engineering properties.

\subsection{Materials Used}

The sand used in the following tests comes from a Libya desert where the sand is abundant and even inhibits construction activities because of its characteristics. The sand was prepared in two forms: the natural desert sand and the crushed sand. Table 1 shows the results of XRF for natural desert sand (NDS) and crushed fine aggregate (CFA). The 
sands were mixed in ratios of 30:70 and 50:50 for crushed sand to natural desert sand, respectively. Ordinary Portland cement (OPC) and fly ash (FA) were secured for use in this laboratory exercise. The OPC was used at a constant percentage of $5 \%$ to modify the desert sands, while FA was applied in the proportions of $0,3,5$, and $7 \%$ by weight of treated sand. The OPC satisfied the conditions of ASTM C150 (1978) while FA satisfied the pozzolana conditions according to ASTM C618 (1978).

Table 1. XRF results of natural desert sand (NFS) and crushed fine aggregate (CFA).

\begin{tabular}{ccc}
\hline Chemical Composition & NFS (\%) & CFA (\%) \\
\hline Silica $\left(\mathrm{SiO}_{2}\right)$ & 83.12 & 87.10 \\
\hline Aluminum $\left(\mathrm{Al}_{2} \mathrm{O}_{3}\right)$ & 11.51 & 8.04 \\
\hline Iron $\left(\mathrm{Fe}_{2} \mathrm{O}_{3}\right)$ & 2.53 & 1.31 \\
\hline Potassium $\left(\mathrm{K}_{2} \mathrm{O}\right)$ & 0.34 & 0.12 \\
\hline Titanium $\left(\mathrm{TiO}_{2}\right)$ & 0.51 & 0.18 \\
\hline Calcium $(\mathrm{CaO})$ & 0.23 & 0.08 \\
\hline Magnesium $(\mathrm{MgO})$ & 0.11 & 2.16 \\
\hline Sulfur $\left(\mathrm{SO}_{3}\right)$ & 1.33 & 0.08 \\
\hline Sodium $\left(\mathrm{Na}_{2} \mathrm{O}\right)$ & 0.12 & 0.93 \\
\hline Barium $(\mathrm{BaO})$ & 0.13 & - \\
\hline Manganese $(\mathrm{MnO})$ & 0.07 & - \\
\hline
\end{tabular}

\subsection{Testing Procedures}

The addition of these materials to the different properties of sand was investigated via the following experiments: the modified proctor test for evaluating OMC and MDD; CBR; as well as the unconfined compression test of the modified desert sands. In the modified proctor test, the weight of the hammer used was $4.54 \mathrm{~kg}$, and its height of fall was $203 \mathrm{~mm}$. The internal diameter and effective height of the mold were $152.4 \mathrm{~mm}$ and $177.8 \mathrm{~mm}$, respectively. The sample layers were compacted individually, after which point the OMC and MDD were calculated. In order to perform the CBR test, water of equal volume to the OMC was added to the soil samples. After compaction, the samples were placed in the CBR testing machine, and the test was verified according to ASTM D1883. To conduct the UCS test, the samples were prepared according to ASTM D2216 in a cylindrical metal mold with an internal diameter of $50 \mathrm{~mm}$ and a height of $100 \mathrm{~mm}$. Then, the samples were subjected to an axial load as per the relevant ASTM. Then, the treated specimens were cured for 7, 14, and $28 \mathrm{~h}$. Figure 1 shows all the materials and experimental procedure. 


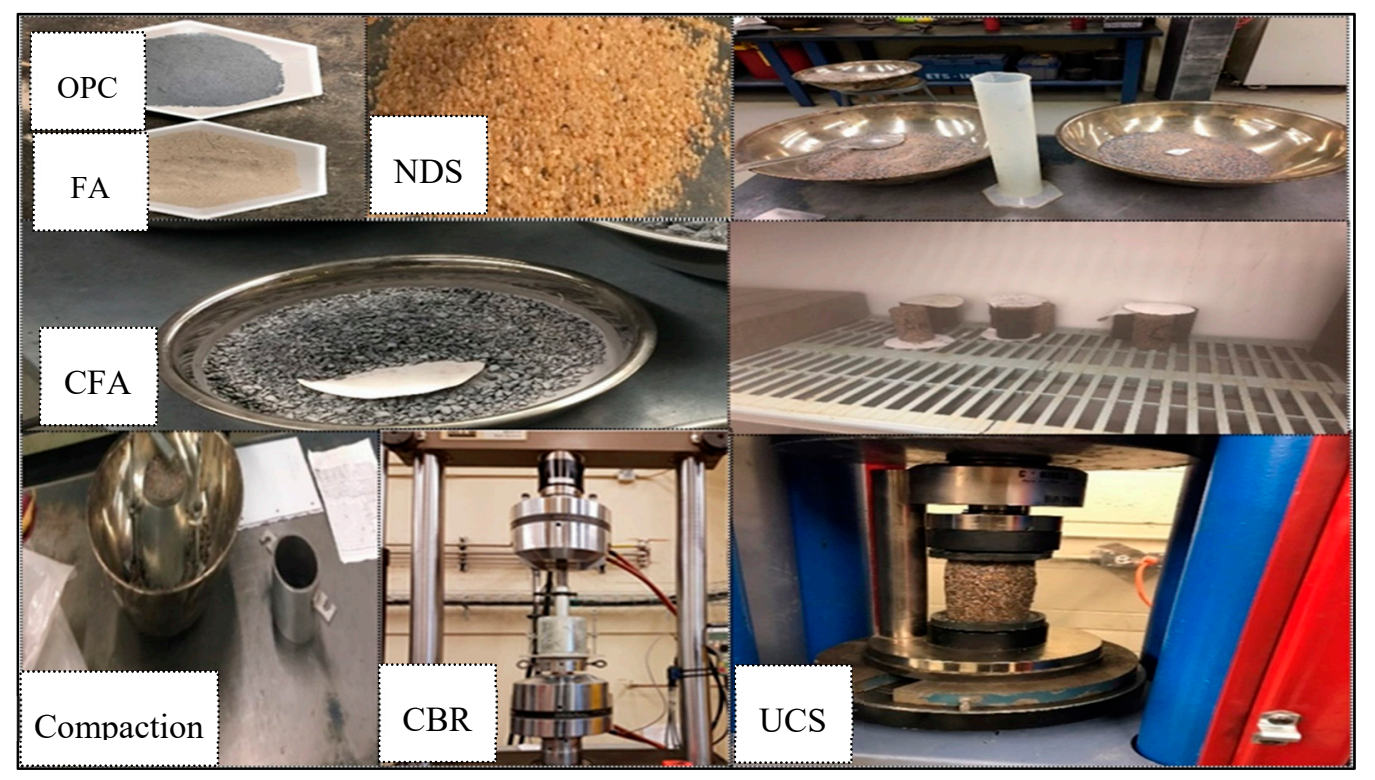

Figure 1. The materials and experimental work.

\section{Results and Discussion}

The compaction characteristics as well as the UCS and CBR values were determined for all soil samples. The results are analyzed and discussed below:

\subsection{General Classification of Test Materials}

The results of the particle size distribution in Table 2 and Figure 2 showed that an equal percentage of both mixtures at $30: 70 \%$ and $50: 50 \%$ passed through sieve no. 10, and variations were observed in percentage passing through the other sieves until a uniform percentage of 0.2 passed through sieve no. 0.080. According to the AASHTO system of soil classification, this soil mix is classified as A-3 (fine sand that would make a good plastering or construction material or modified mortar). Desert sands are classified as having similar consistency to dune sands or river sand with no plasticity. Table 3 presents the composition of the chemical oxide of the binding materials, which were cement utilized at a fixed $5 \%$ proportion by weight of treated desert sand. Table 3 shows that fly ash is predominantly more rich in aluminosilicates than cement, which is predominantly rich in calcium oxide. According to the requirements for pozzolanas in American Standard for Testing and Materials ASTM C618-19, FA is considered a pozzolanic material; the sum of the composition of silica, alumina, and ferrite is more than $70 \%$, as presented in Table 3 . This property makes FA a good environmentally friendly supplementary cementitious material (SCM) with special properties to resist shrinkage potentials, cracking effect, high temperatures, sulfate attacks, etc., unlike the OPC, which is prone to cracking, sulfate attacks, and temperature effects.

\subsection{Compaction Behavior of FA-Treated Desert Sand}

The influence of a fixed percentage of the cement modified desert soil, mixed with the ratio of $30: 70 \%$ and $50: 50 \%$ for crushed and natural desert sands and treated with FA at proportions of 3,5 , and $7 \%$ respectively by weight, on the dry density and moisture content of the soil mixture are shown in Figures 3 and 4 . The maximum dry density (MDD) of both mixtures increases with an observed increase in fly ash content (i.e., 0 to $7 \%$ ). It was found that the 30:70 mix specimen increased substantially with increased fly ash dosages, although a greater increase was observed in the 50:50 mixture. In addition, it was found that the MDD increased from 1.8 to $2.10 \mathrm{gr} / \mathrm{cm}^{3}$, while the optimum moisture content (OMC) decreased from $5.09 \%$ to $4.45 \%$ with a proportional increase of $7 \%$ in $\mathrm{FA}$ for the mixture of 30:70. The same trend was found for the 50:50 mixture. Furthermore, the MDD improved at an index of $3.96 \%$ in the $30: 70$ mix specimen treated with fly ash, 
while it improved at an index of $3.16 \%$ with the $50: 50$ mix specimen. The results show that natural desert sand, which is higher in the 30:70 mix specimen, played a substantial role in the significant improvement recorded. It can be assumed that desert sand in its natural state will be better than crushed sand. This is due to the loss of textural strength and particle-to-particle intergranular force during the crushing of desert sand. Furthermore, it was concluded that the cation exchange reaction responsible for densification will be greater in the 30:70 mix with a higher proportion of natural desert sand than in the 50:50 mix specimen. A hydration reaction resulted in an overall reduction in the use of the available moisture. This was because moisture was needed to chemically break down the materials into $\mathrm{Ca}^{2+}$ and $\mathrm{OH}^{-}$ions, thereby facilitating an exchange reaction and producing more $\mathrm{Ca}^{2+}$ [29]. The results show that the use of OPC in the stabilized mix has played a major role in the improvement of the achieved CBR values. A similar result was also offered by [30], where samples with $4 \%$ cement content (5\% FA content) proved to be much more viable than $2 \%$ cement content samples, where there was no significant improvement after 14 days of curing.

Table 2. Particle size distribution of test sands.

\begin{tabular}{ccc}
\hline Diameter $(\mathbf{m m})$ & Mixture $\mathbf{3 0 : 7 0 \%}$ & Mixture 50:50\% \\
\hline 28.00 & 100 & 100 \\
\hline 20.00 & 100 & 100 \\
\hline 14.00 & 100 & 100 \\
\hline 10.00 & 98.4 & 98.4 \\
\hline 5.00 & 41.8 & 59.7 \\
\hline 2.50 & 24.7 & 43.6 \\
\hline 1.25 & 7.2 & 7.6 \\
\hline 0.63 & 5.3 & 4.5 \\
\hline 0.32 & 2.8 & 1.9 \\
\hline 0.16 & 1.6 & 1 \\
\hline 0.080 & 0.2 & 0.2 \\
\hline
\end{tabular}

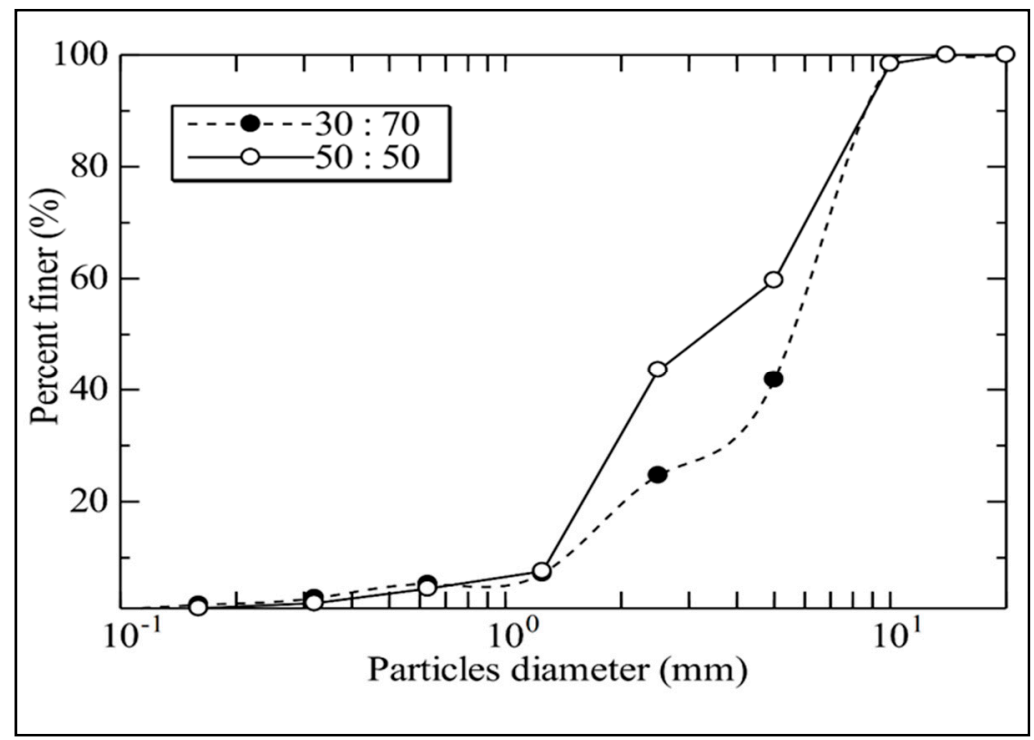

Figure 2. Gradation curves for two mixtures of sand (30:70\% and 50:50\%). 
Table 3. Chemical composition of OPC and FA.

\begin{tabular}{ccc}
\hline \multirow{2}{*}{ Compound } & OPC & FA \\
\cline { 2 - 3 } & \% Composition & \% Composition \\
\hline $\mathrm{SiO}_{2}$ & 18.20 & 62.04 \\
\hline $\mathrm{CaO}$ & 59.03 & 9.10 \\
\hline $\mathrm{MgO}$ & 1.80 & 1.03 \\
\hline $\mathrm{Al}_{2} \mathrm{O}_{3}$ & 5.09 & 17.21 \\
\hline $\mathrm{Fe}_{2} \mathrm{O}_{3}$ & 3.15 & 4.10 \\
\hline $\mathrm{Na}_{2} \mathrm{O}$ & 0.18 & 0.03 \\
\hline $\mathrm{K}_{2} \mathrm{O}$ & 0.29 & 1.21 \\
\hline $\mathrm{SO}_{3}$ & 2.65 & 3.88 \\
\hline Loss on Ignition (LOI) & 7.91 & 0.43 \\
\hline Un-solvent materials & 1.02 & - \\
\hline
\end{tabular}

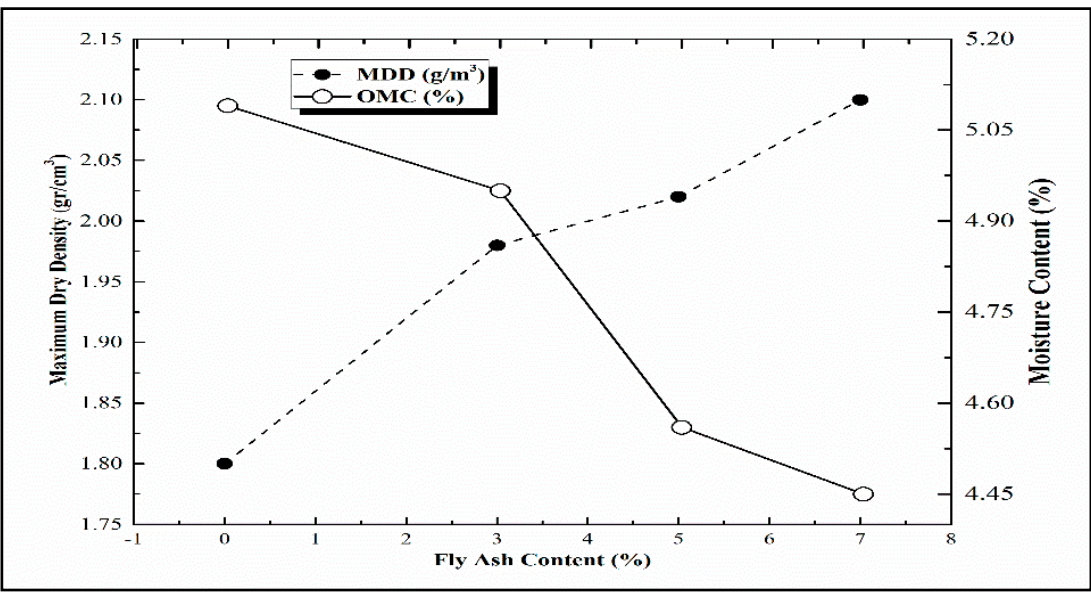

Figure 3. Effect of FA on the compaction of cement-modified desert soil (30:70).

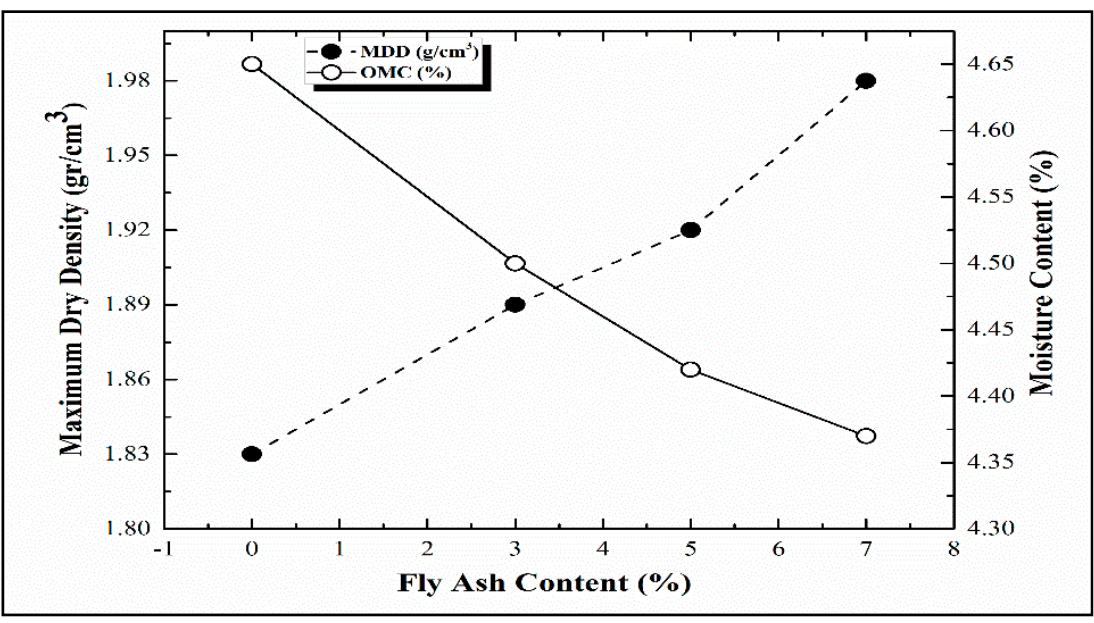

Figure 4. Effect of FA on the compaction of cement-modified desert soil (50:50).

\subsection{Strenght Behavior of FA Treated Desert Sand}

The CBR test results for samples 30:70 and 50:50 treated with FA at the ratios of 0, 3,5 , and $7 \%$ and cement kept at a constant proportion of 5\% are shown in Table 4 and Figure 5. The CBR values of mix 30:70 at both $2.5 \mathrm{~mm}$ and $5 \mathrm{~mm}$ penetration have shown 
better performance than the values of the 50:50 mix. The first mix showed substantial improvement in the CBR due to the higher proportion of fines in the crushed sand. With added FA, CBR showed regular improvement; this might be because enough calcium is freed when calcium aluminate (CA) and hydrated calcium silicate (CS) are formed. It is well established that these are the compounds that result in improved strength. It should be noted that the greatest CBR values (30:70) were found when the soils were treated with a $7 \%$ addition of FA for both penetrations at $2.5 \mathrm{~mm}$ and $5 \mathrm{~mm}$. This result suggests that an increase in FA amount in cement-modified desert soil produces a better stabilization result in terms of CBR values, and this improvement may be attributed to the change of soil structure from dispersed to flocculate.

Table 4. Effect of fly ash on the CBR of cement-modified desert soil.

\begin{tabular}{|c|c|c|c|c|c|c|c|c|}
\hline \multirow[t]{2}{*}{ Penetration (mm) } & \multicolumn{4}{|c|}{$\begin{array}{c}\text { CFA/NDS Ratio 30:70 } \\
\text { with 5\% OPC }\end{array}$} & \multicolumn{4}{|c|}{$\begin{array}{l}\text { CFA/NDS Ratio 50:50 } \\
\text { with 5\% OPC }\end{array}$} \\
\hline & 0 & 3 & 5 & 7 & 0 & 3 & 5 & 7 \\
\hline $\begin{array}{c}2.5 \mathrm{~mm} \\
\text { CBR }(\%)\end{array}$ & 82.20 & 83.20 & 84.80 & 86.30 & 52.17 & 52.1 & 52.75 & 53.81 \\
\hline $\begin{array}{c}5 \mathrm{~mm} \\
\text { CBR }(\%)\end{array}$ & 62.40 & 63.40 & 64.10 & 64.70 & 49.32 & 49.11 & 49.87 & 50.04 \\
\hline
\end{tabular}
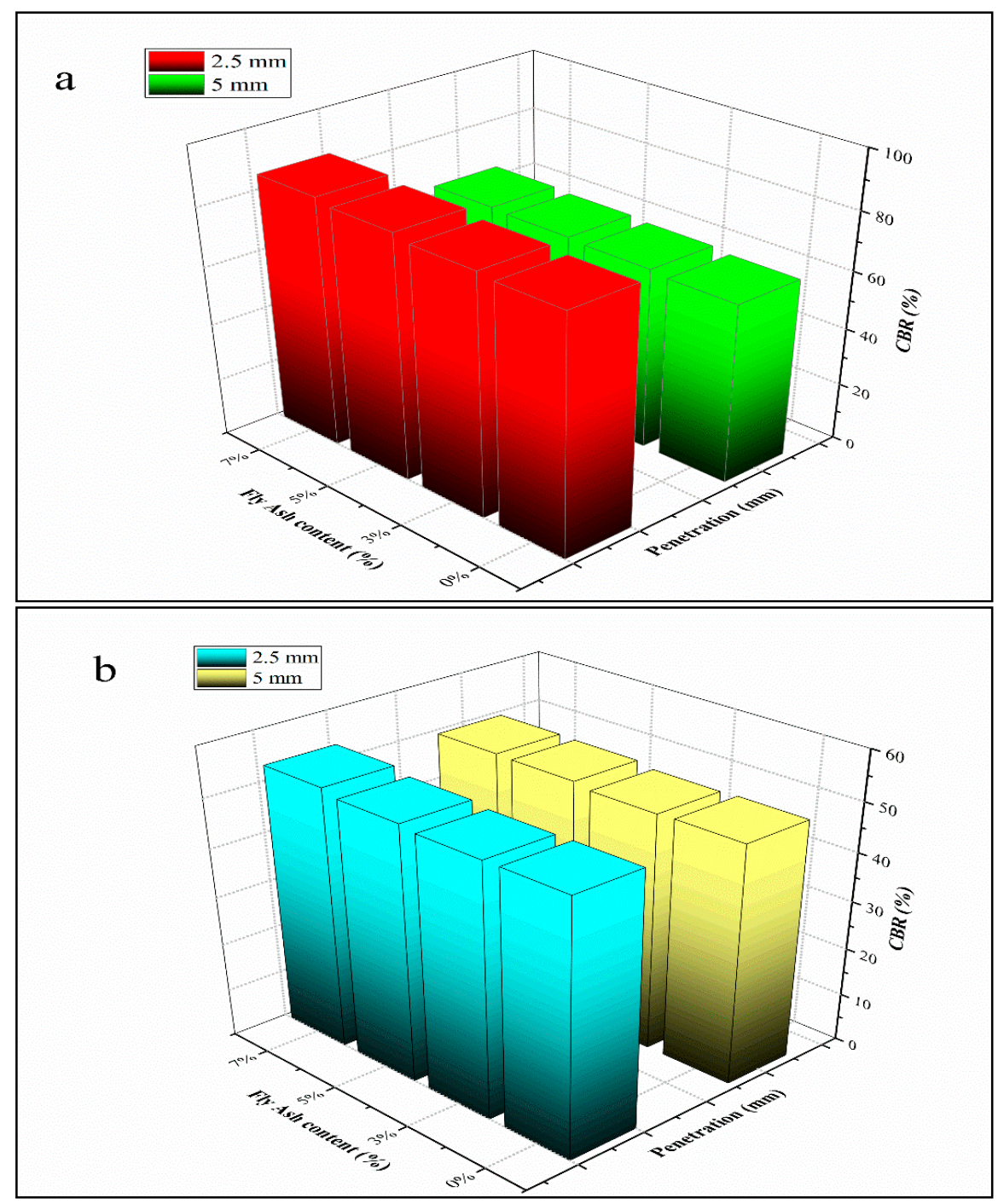

Figure 5. Effect of FA on the CBR of cement modified desert sand: (a): 30:70\%, (b). 50:50\%. 


\subsection{Compression Behavior of FA-Treated Desert Sand}

Figures 6 and 7 show the UCS results test. The increase in FA and the resulting cement hydration result in improved bonding strength, indicating an interdependence within the mixture where the air voids are filled. This makes the structure more rigid due to a greater number of bonds in the material. Following a 28-day curing period, the USC was found to be markedly better, going from 0.88 to $4.740 \mathrm{MPa}$ and 0.88 to $4.250 \mathrm{MPa}$, when the FA percentage was raised from 3\% to $7 \%$ in both the $30: 70$ and in the $50: 50$ mixes, respectively. Nonetheless, the highest UCS value, $4.74 \mathrm{MPa}$, was found using a ratio of $30: 70$ and $7 \% \mathrm{FA}$, when the sample was given 28 days to cure, which was about seven times more than the soil before treatment.

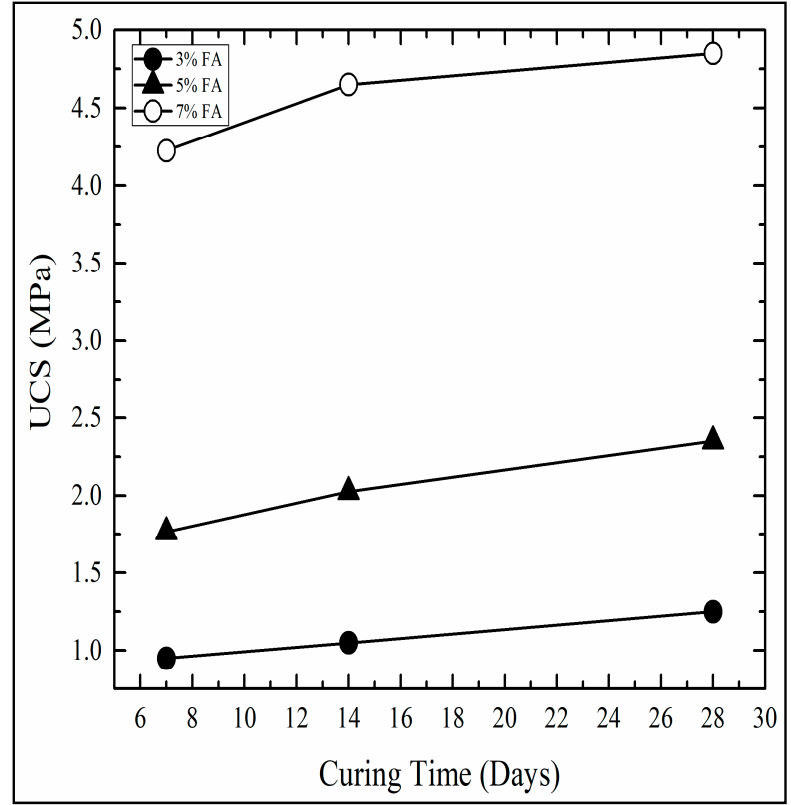

(a)

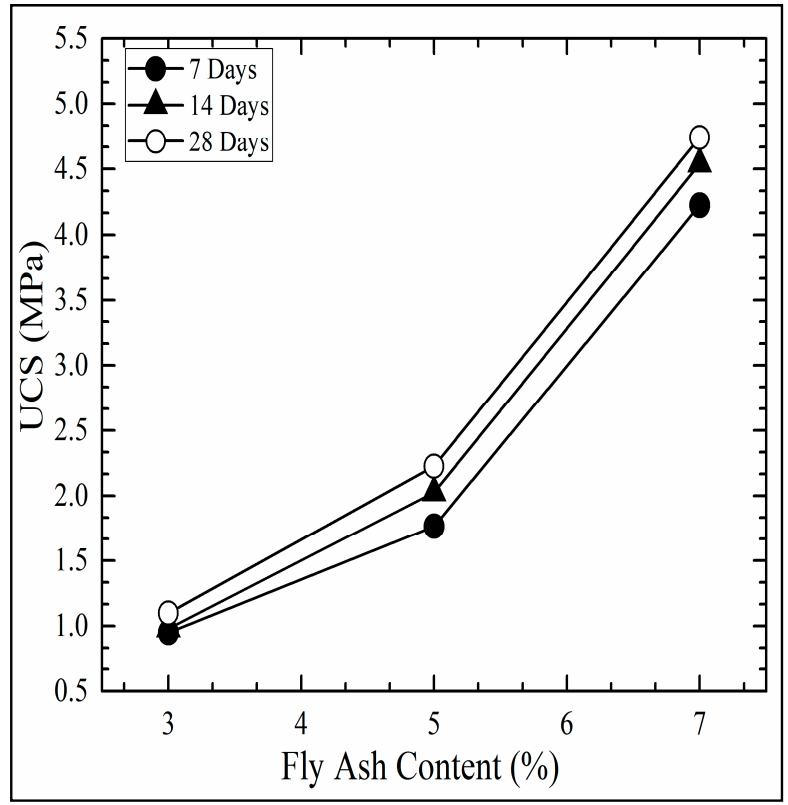

(b)

Figure 6. Effect of FA on the UCS and different curing time $(7,14$, and 28 days) for the 30:70 treat mixtures.

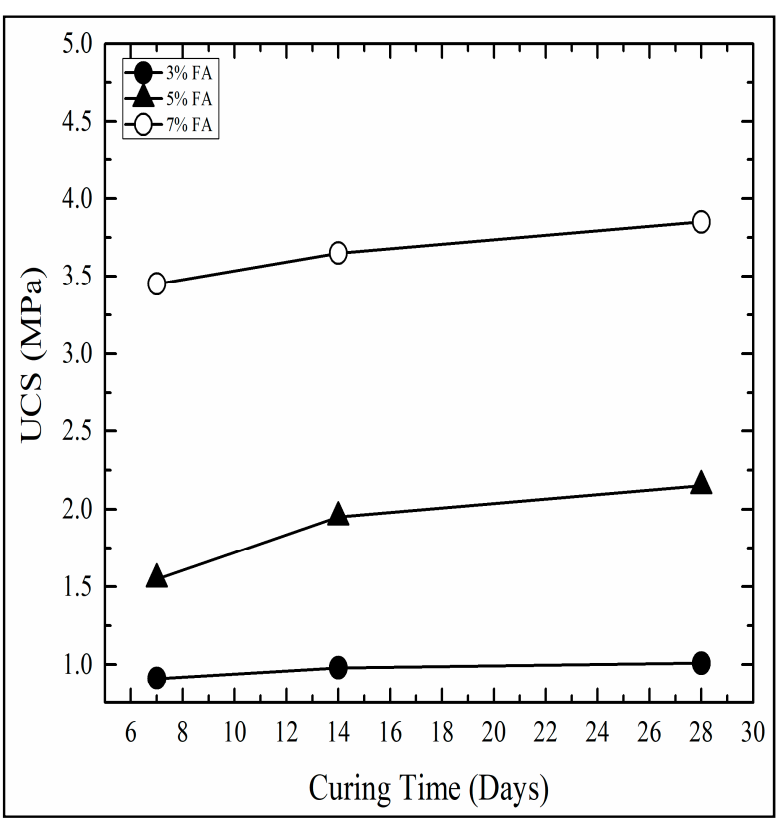

(a)

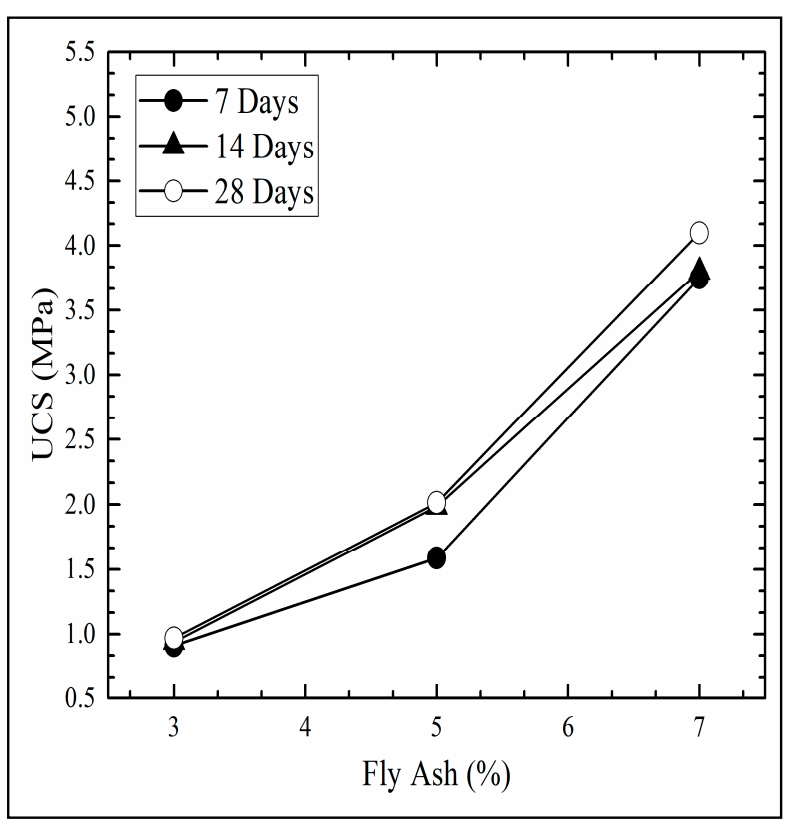

(b)

Figure 7. Effect of FA on the UCS and different curing time $(7,14$, and 28 days) for the 50:50 treat mixtures. 


\subsection{Structural Analysis}

The increase in the CBR of the natural sand from $23 \%$ to $86.3 \%$, as a result of the addition of $30 \%$ coarse aggregates $(30 \%: 70 \%)$ with $7 \%$ FA and $5 \%$ OPC, has a meaningful impact on the structural design of the pavement.

Considering that the modulus of resilience of the base and subbase courses can be estimated with the equation: $\mathrm{M}_{\mathrm{r}}=10.34{ }^{*} \mathrm{CBR}$ [31], then we can safely assume a three-fold increase of the modulus from 230 to $890 \mathrm{MPa}$. As a result, Figure 8 compares the tensile strain at the bottom of a $50 \mathrm{~mm}$ thick asphalt concrete surface with a conventional modulus of $1000 \mathrm{MPa}$ resting on a base course with a modulus of $230 \mathrm{MPa}$ (strain Y of 476 microns) vs. $890 \mathrm{MPa}$ (strain $\mathrm{Y}$ of 161 microns). The reduction in the maximum tensile strain at the bottom of the asphalt concrete, which controls wheel path cracking, from 476 microns down to 161 microns, has a substantial impact on the amount of equivalent single axle loads (ESAL) the pavement can withstand before such cracking occurs. This substantial extension of the pavement structural life is due to the logarithmic nature of the ESAL vs. tensile strain relationship.

The Asphalt Institute (1982) relationship [32] between tensile strain at the bottom of the asphalt concrete (AC) under one single axle load and the number of repetitions of the axle load until fatigue failure of the AC occurs is as follows:

$$
\mathrm{N}_{\mathrm{f}}=0.0796\left(\varepsilon_{\mathrm{t}}\right)^{-3.291}(\mathrm{E})^{-0.854}
$$

where

$\mathrm{N}_{\mathrm{f}}$ : Number of 8-ton axle load applications to failure, i.e., cracking occurs at bottom of AC; $\varepsilon_{\mathrm{t}}$ : Horizontal tensile strain at the bottom of asphalt layer $\left(476 \times 10^{-6}\right.$ or $\left.161 \times 10^{-6}\right)$;

E: Elastic modulus of the AC (1000 MPa or 145,000 psi).

Therefore, the reduction of the tensile strain in the AC from 476 microns to 161 microns results in an increase in the structural life of the pavement from 267,000 8-ton axle loads to 9,472,000 8-ton axle loads or over thirty-five times (35X), which is in accordance with the Asphalt Institute formula (E in psi), before fatigue cracking is developed in the $\mathrm{AC}$ wheel paths.

\subsection{Cost Analysis}

An assessment of the economic benefits was conducted on data obtained from the Libyan Ministry of Bridges and Roads on a proposed $120 \mathrm{~km}$ road in the south of Libya with varying subgrade soil conditions. A section of about $6 \mathrm{~km}$, between the cities of Sabha and Al Mrugah, with subgrade soil properties similar to those of the control soil in this study was selected as a basis for comparison. From the comparison between the untreated base pavement and Figure 8, the asphaltic layer thickness was decreased from $100 \mathrm{~mm}$ for untreated subgrade to $50 \mathrm{~mm}$ in case of treated subgrade. In addition, the base thickness was decreased from 400 to $300 \mathrm{~mm}$ for the untreated and treated base course, respectively. The thickness reduction of these layers can, substantially, reduce the overall cost of the project without any adverse effects on the structural properties of the pavements system.

In the Sahar desert in Libya, one square meter of asphaltic mixture and granular base with a thickness of $10 \mathrm{~mm}$ costs about $\$ 3$ and $\$ 0.25$, respectively, while the cost of cement is $110 \$ /$ ton. Therefore, the savings amount to $15 \$ / \mathrm{m}^{2}$ for the asphalt as a result of the reduction of thickness from 100 to $50 \mathrm{~mm}$, and an additional saving of $2.5 \$ / \mathrm{m}^{2}$ for the aggregate as a result of the reduction of thickness from 400 to $300 \mathrm{~mm}$. The cost of cement to stabilize $300 \mathrm{~mm}$ at a OPC of $5 \%$ equates to about $4 \$ / \mathrm{m}^{2}$ for the cement and $3.5 \$ / \mathrm{m}^{2}$ for mixing for a net saving of about $10 \$ / \mathrm{m}^{2}$ if the base is modified by the optimum FA dose and $5 \%$ OPC. Therefore, the initial cost of $40 \$ / \mathrm{m}^{2}$ is reduced to $30 \$ / \mathrm{m}^{2}$ or $25 \%$, as shown in Figure 9. 


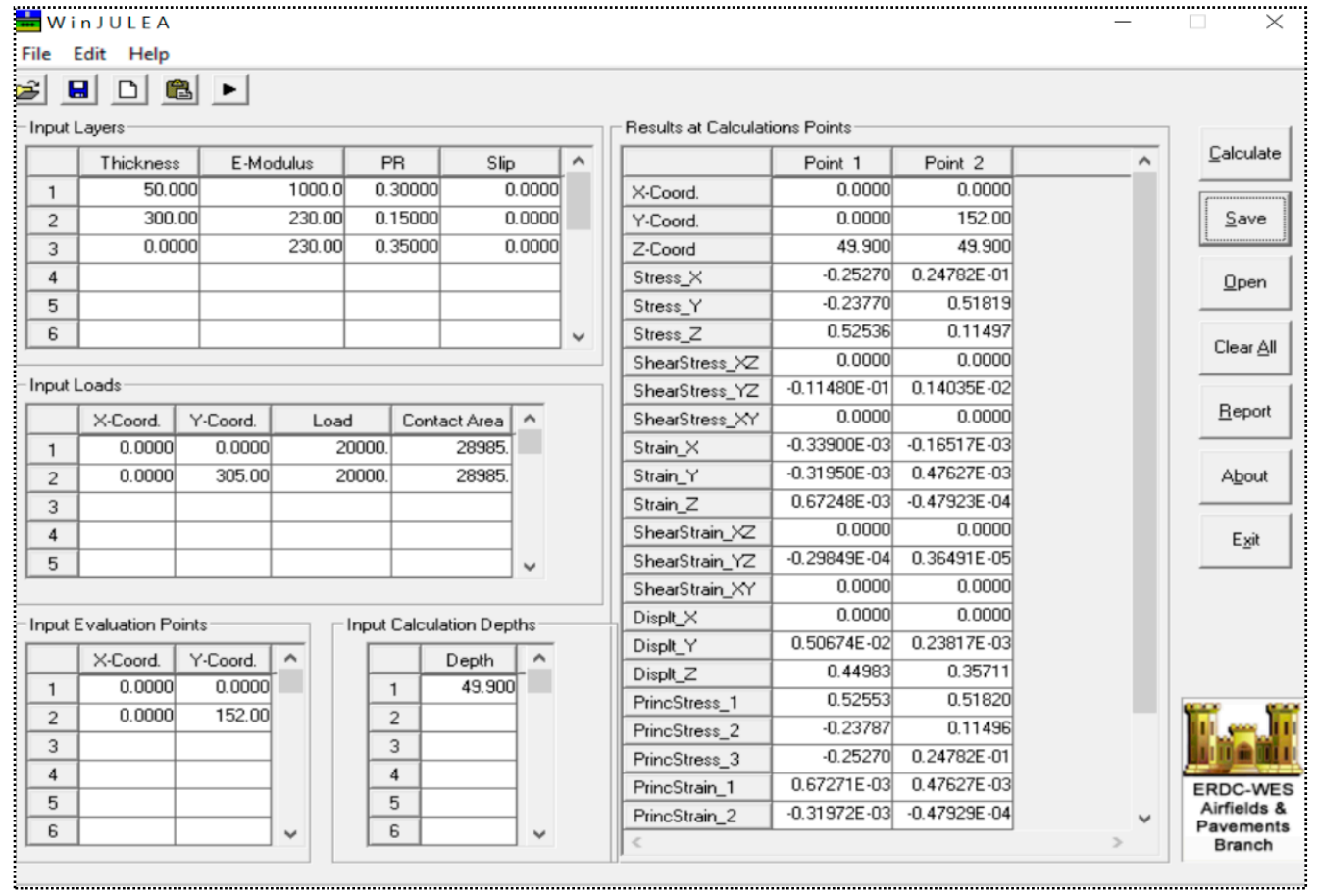

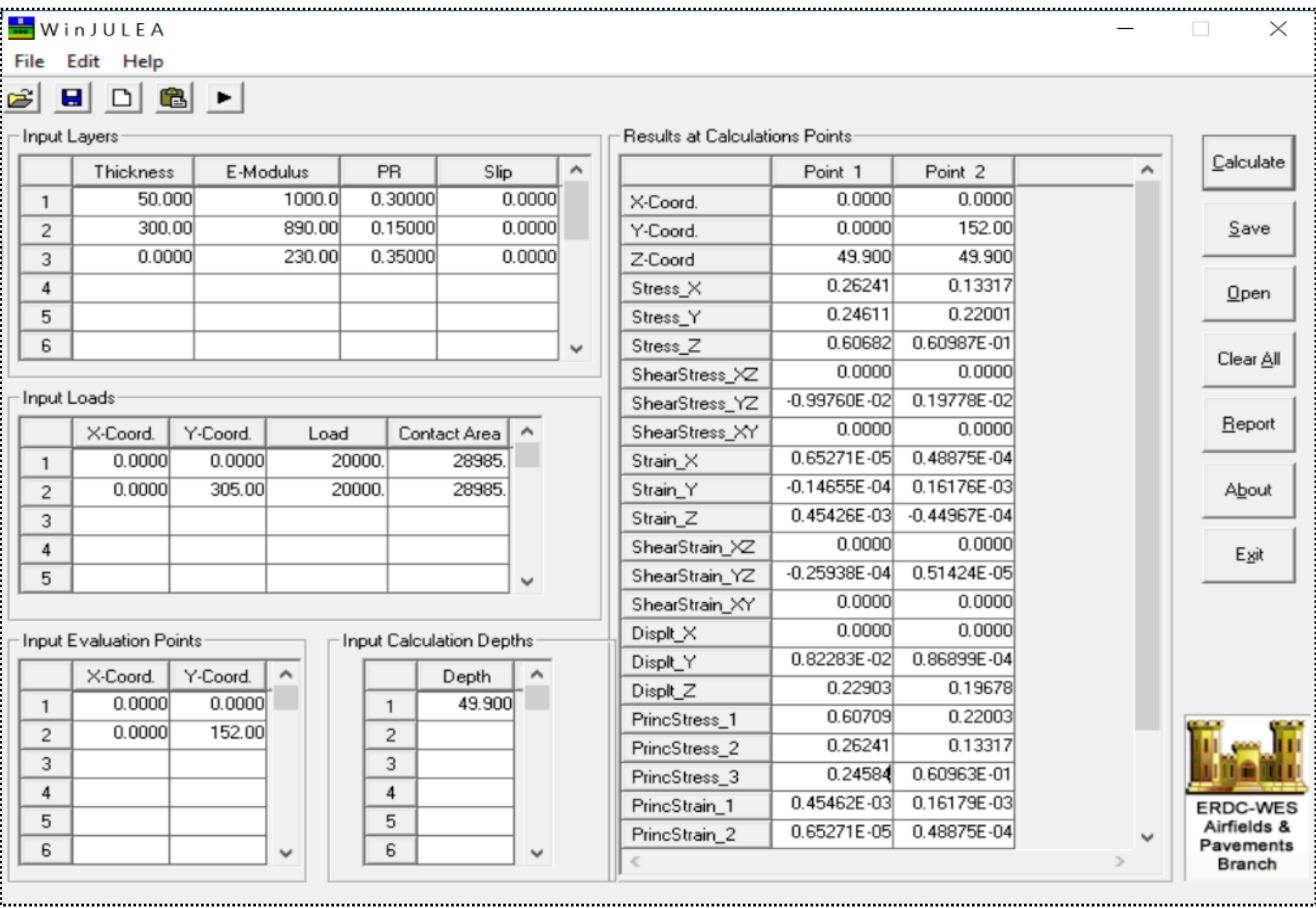

Figure 8. Thickness saving in pavement layers for untreated and treated base. 


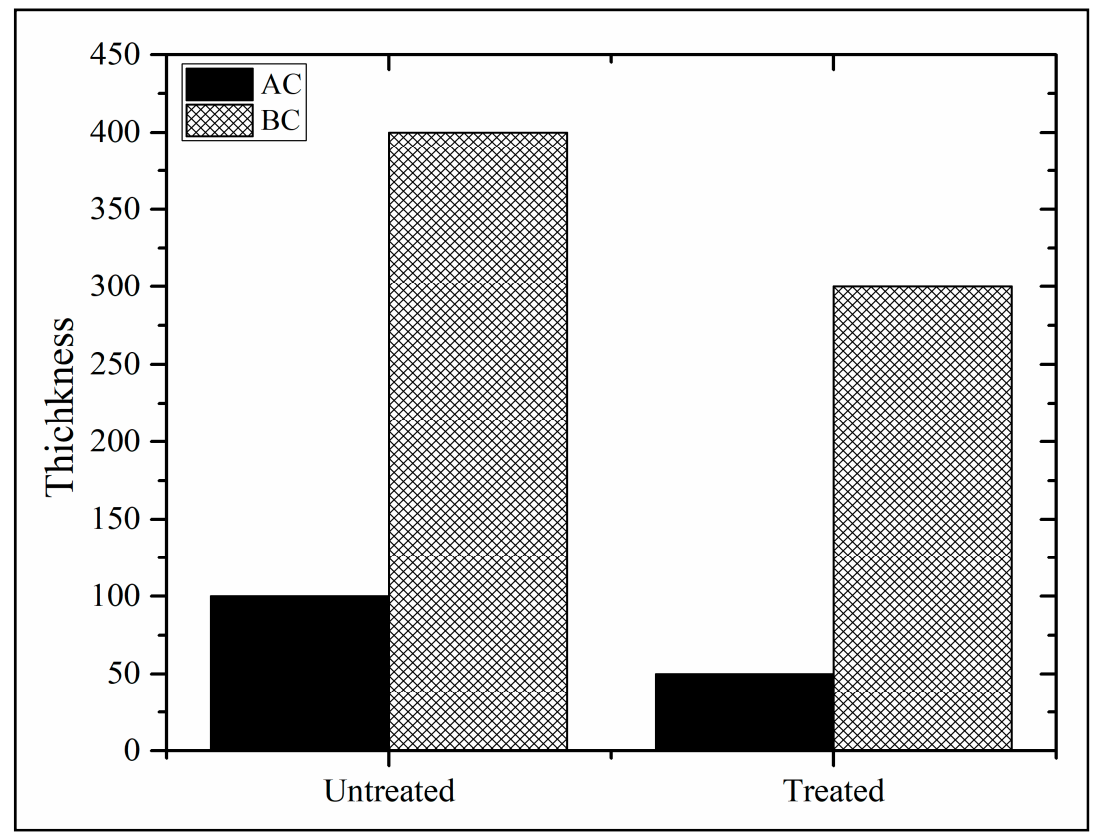

Figure 9. Comparative structural analysis $(100 \% ; 0 \%)$ on top of figure vs. $(30 \%: 70 \%)$ and $7 \%$ FA $+5 \%$ OPC at bottom of figure.

\section{Conclusions}

Based on the results of the different laboratory tests performed on the cement-modified desert sand treated with fly ash, the following conclusions can be drawn:

(i) Desert sand can be used as a reliable construction material if improved with cement to meet the strength requirements, and the thickness of both the base and asphalt layers may be substantially reduced ( $50 \%$ for the asphalt and $25 \%$ for the base) for a net saving of approximately $25 \%$ of the cost of the road.

(ii) The unconfined compressive strength and bearing resistance of the treated sand was found to increase with the increase in fly ash content and curing time. Using the high amount of FA (about 7\%) can significantly improve the engineering properties of the natural sand.

(iii) The use of local and available material such as desert sand reduces the polluting emissions of the production and the transportation.

(iv) Stabilized based using mixed cement and fly ash effectively improves the pavement properties. This causes a considerable increase in the number of permissible equivalent wheel load and consequently increases the lifetime of the road, respectively.

(v) This technique will be also more competitive in coal-producing countries (which have a great amount of fly ash to dispose) and with a lack of calcareous materials for cement production.

Author Contributions: T.S.A. and G.J.A. contributed to the design and implementation of the research as well as the analysis of the results. T.S.A. wrote the manuscript. All authors have read and agreed to the published version of the manuscript.

Funding: This research received no external funding.

Institutional Review Board Statement: Not applicable.

Informed Consent Statement: Not applicable.

Data Availability Statement: The data supporting the results of this research work are reported in the manuscript.

Acknowledgments: The authors would like to thank the Department of Construction Engineering at École de Technologie Supérieure (ETS), University of Quebec, for providing all the facilities to carry 
out the experiments. Also, we wish to express our gratitude to the anonymous reviewers for the comments and suggestions provided, which have been very helpful in improving the paper.

Conflicts of Interest: The authors declare no conflict of interest.

\section{References}

1. Raheel, M.; Khan, R.; Khan, A.; Khan, M.T.; Ali, I.; Alam, B.; Wali, B. Impact of axle overload, asphalt pavement thickness and subgrade modulus on load equivalency factor using modified ESALs equation. Cogent Eng. 2018, 5, 1528044. [CrossRef]

2. Pasindu, H.; Gamage, D.; Bandara, J. Framework for selecting pavement type for low volume roads. Transp. Res. Procedia 2020, 48, 3924-3938. [CrossRef]

3. Tsubota, T.; Fernando, C.; Yoshii, T.; Shirayanagi, H. Effect of Road Pavement Types and Ages on Traffic Accident Risks. Transp. Res. Procedia 2018, 34, 211-218. [CrossRef]

4. Cheng, H.; Liu, L.; Sun, L.; Li, Y.; Hu, Y. Comparative analysis of strain-pulse-based loading frequencies for three types of asphalt pavements via field tests with moving truck axle loading. Constr. Build. Mater. 2020, 247, 118519. [CrossRef]

5. Chen, Y.; Saha, S.; Lytton, R.L. Prediction of the pre-erosion stage of faulting in jointed concrete pavement with axle load distribution. Transp. Geotech. 2020, 23, 100343. [CrossRef]

6. Han, Z.; Yang, L.; Fang, H.; Zhang, J. Dynamic simulation of falling weight deflectometer tests on flexible transversely isotropic layered pavements. Soil Dyn. Earthq. Eng. 2020, 139, 106353. [CrossRef]

7. Zhang, J.; Zhang, A.; Huang, C.; Yu, H.; Zhou, C. Characterising the resilient behaviour of pavement subgrade with construction and demolition waste under Freeze-Thaw cycles. J. Clean. Prod. 2021, 300, 126702. [CrossRef]

8. Abukhettala, M.; Fall, M. Geotechnical characterization of plastic waste materials in pavement subgrade applications. Transp. Geotech. 2021, 27, 100472. [CrossRef]

9. Li, Y.; Cui, J.; Zhang, T.; Okuro, T.; Drake, S. Effectiveness of sand-fixing measures on desert land restoration in Kerqin Sandy Land, northern China. Ecol. Eng. 2009, 35, 118-127. [CrossRef]

10. Neumann, F.; Curbach, M. Thermal treatment of desert sand to produce construction material. In MATEC Web of Conferences; EDP Sciences: Ulis, France, 2018; p. 01030.

11. Abderrahmane, G.; Ratiba, M.K. Stabilized dune sand for road foundation layers-case of the dune sand of the region of Djelfa (Algeria). In Applied Mechanics and Materials; Trans Tech Publications Ltd.: Baech, Switzerland, 2013; pp. 263-277.

12. Al-Aghbari, M.Y.; Mohamedzein, Y.E.-A.; Taha, R. Stabilisation of desert sands using cement and cement dust. Proc. Inst. Civ. Eng. Ground Improv. 2009, 162, 145-151. [CrossRef]

13. Amel, C.L.; Kadri, E.-H.; Sebaibi, Y.; Soualhi, H. Dune sand and pumice impact on mechanical and thermal lightweight concrete properties. Constr. Build. Mater. 2017, 133, 209-218. [CrossRef]

14. Haifeng, L.; Jurong, M.; Yiying, W.; Jianguo, N. Influence of desert sand on the mechanical properties of concrete subjected to impact loading. Acta Mech. Solida Sin. 2017, 30, 583-595. [CrossRef]

15. Luo, F.J.; He, L.; Pan, Z.; Duan, W.H.; Zhao, X.L.; Collins, F. Effect of very fine particles on workability and strength of concrete made with dune sand. Constr. Build. Mater. 2013, 47, 131-137. [CrossRef]

16. Che, J.; Wang, D.; Liu, H.; Zhang, Y. Mechanical Properties of Desert Sand-Based Fiber Reinforced Concrete (DS-FRC). Appl. Sci. 2019, 9, 1857. [CrossRef]

17. Rahman, I.U.; Raheel, M.; Khawaja, M.W.A.; Khan, R.; Li, J.; Khan, A.; Khan, M.T. Characterization of engineering properties of weak subgrade soils with different pozzolanic \& cementitious additives. Case Stud. Constr. Mater. 2021, 15, e00676. [CrossRef]

18. Miricioiu, M.G.; Niculescu, V.C.; Filote, C.; Raboaca, M.S.; Nechifor, G. Coal Fly Ash Derived Silica Nanomaterial for MMMsApplication in CO2 / CH4 Separation. Membranes 2021, 11, 78. [CrossRef] [PubMed]

19. Karami, H.; Pooni, J.; Robert, D.; Costa, S.; Li, J.; Setunge, S. Use of secondary additives in fly ash based soil stabilization for soft subgrades. Transp. Geotech. 2021, 29, 100585. [CrossRef]

20. Teing, T.T.; Huat, B.B.; Shukla, S.K.; Anggraini, V.; Nahazanan, H. Effects of alkali-activated waste binder in soil stabilization. Int. J. Geomate 2019, 17, 82. [CrossRef]

21. Amhadi, T.S.; Assaf, G.J. Assessment of strength development of cemented desert soil. Int. J. Low-Carbon Technol. 2019, 14, 543-549. [CrossRef]

22. Cong, M.; Longzhu, C.; Bing, C. Analysis of strength development in soft clay stabilized with cement-based stabilizer. Constr. Build. Mater. 2014, 71, 354-362. [CrossRef]

23. Rahgozar, M.A.; Saberian, M. Geotechnical properties of peat soil stabilised with shredded waste tyre chips. Mires Peat 2016, 18, 1-12. [CrossRef]

24. Saberian, M.; Khabiri, M.M. Effect of oil pollution on function of sandy soils in protected deserts and investigation of their improvement guidelines (case study: Kalmand area, Iran). Environ. Geochem. Health 2018, 40, 243-254. [CrossRef]

25. Wong, L.S.; Hashim, R.; Ali, F. Utilization of sodium bentonite to maximize the filler and pozzolanic effects of stabilized peat. Eng. Geol. 2013, 152, 56-66. [CrossRef]

26. Al-Aghbari, M.Y.; Dutta, R.K. Suitability of desert sand cement mixes for base courses in highway pavements. Electron. J. Geotech. Eng. 2005, 10.

27. Rahardjo, H.; Gofar, N.; Satyanaga, A. Effect of concrete waste particles on infiltration characteristics of soil. Environ. Earth Sci. 2018, 77, 347. [CrossRef] 
28. Amu, O.; Fajobi, A.B.; O Afekhuai, S. Stabilizing Potential of Cement-Fly Ash Mixture on Expansive Clay Soil. J. Technol. Educ. Niger. 2008, 12, 1-8. [CrossRef]

29. Onyelowe, K.C.; Aririguzo, J.C.; Ezugwu, C.N. Sustainable Soils Re-Engineering; Partridge Publishing: Singapore, 2019.

30. Kolias, S.; Kasselouri-Rigopoulou, V.; Karahalios, A. Stabilisation of clayey soils with high calcium fly ash and cement. Cem. Concr. Compos. 2005, 27, 301-313. [CrossRef]

31. Hussein, A.A.; Alshkane, Y.M. Prediction of CBR and MR of Fine-Grained Soil Using DCPI. In Proceedings of the International Engineering Conference on Developments in Civil \& Computer Engineering, Erbil, Iraq, 26-27 February 2018; pp. 262-268.

32. Ekwulo, E.O.; Eme, D.B. Fatigue and rutting strain analysis of flexible pavements designed using CBR methods. Afr. J. Environ. Sci. Technol. 2009, 3, 412-421. 